\title{
Building Bridges with Boats: Preserving Community History through Intra- and Inter-Institutional Collaboration
}

\author{
Kathleen Spring \\ Linfield College \\ Brenda DeVore Marshall \\ Linfield College
}

Follow this and additional works at: https://digitalcommons.linfield.edu/librariesfac_pubs

Part of the Library and Information Science Commons, Oral History Commons, and the Speech and Rhetorical Studies Commons

\section{DigitalCommons@Linfield Citation}

Spring, Kathleen and Marshall, Brenda DeVore, "Building Bridges with Boats: Preserving Community History through Intra- and Inter-Institutional Collaboration" (2013). Faculty \& Staff Publications. Accepted Version. Submission 9.

https://digitalcommons.linfield.edu/librariesfac_pubs/9

This Accepted Version is protected by copyright and/or related rights. It is brought to you for free via open access, courtesy of DigitalCommons@Linfield, with permission from the rights-holder(s). Your use of this Accepted Version must comply with the Terms of Use for material posted in DigitalCommons@Linfield, or with other stated terms (such as a Creative Commons license) indicated in the record and/or on the work itself. For more information, or if you have questions about permitted uses, please contact digitalcommons@linfield.edu. 
Building Bridges with Boats

Building Bridges with Boats: Preserving Community History through

Intra- and Inter-Institutional Collaboration

Kathleen Spring a and Brenda DeVore Marshall ${ }^{\mathrm{b}}$

a Jereld R. Nicholson Library, Linfield College, McMinnville, OR, USA

${ }^{b}$ Department of Theatre and Communication Arts, Linfield College, McMinnville, OR, USA 


\begin{abstract}
This chapter discusses Launching through the Surf: The Dory Fleet of Pacific City, a project which documents the historical and contemporary role of dory fishers in the life of the coastal village of Pacific City, Oregon, U.S. Linfield College's Department of Theatre and Communication Arts, its Jereld R. Nicholson Library, the Pacific City Arts Association, the Pacific City Dorymen's Association, and the Linfield Center for the Northwest joined forces to engage in a collaborative college and community venture to preserve this important facet of Oregon's history. Using ethnography as a theoretical grounding and oral history as a method, the project utilized artifacts from the dory fleet to augment interview data, and faculty/student teams created a searchable digital archive available via open access. The chapter draws on the authors' experiences to identify a philosophy of strategic collaboration. Topics include project development and management, assessment, and the role of serendipity. In an era of value-added services where libraries need to continue to prove their worth, partnering with internal and external entities to create content is one way for academic libraries to remain relevant to agencies that do not have direct connections to higher education. This project not only developed a positive "town and gown" relationship with a regional community, it also benefited partner organizations as they sought to fulfill their missions. The project also serves as a potential model for intra- and inter-agency collaboration for all types of libraries.
\end{abstract}

Keywords: communities and higher education; collaboration; digital collections; library partnerships; oral history; project management 
"When the role of libraries is seen in terms of the fundamental character of social order and community development, that role acquires a certain gravitas. In order best to achieve this goal, thereby exemplifying the fundamental value of democracy itself, it stands to reason that library partnerships rise to a new level of significance." (Gaetz, 2009, p. 3)

\section{Introduction}

Launching through the Surf: The Dory Fleet of Pacific City (otherwise known as the Dory Project) is an interdisciplinary, collaborative, scholarly, and creative research project centered on a small northwestern U.S. coastal community. Emphasizing both historical and contemporary perspectives, the project involves collecting oral histories from individuals associated with the Pacific City (Oregon) Dory Fleet. The Dory Project exemplifies the complexities of both intraand inter-institutional collaborations, and in the sections that follow we highlight the various elements that made the Dory Project possible. We begin by outlining the project partners and stated goals, moving on to identify a philosophy of strategic collaboration and the unique contributions this project makes to the professional literature. We then describe the development of the project, focusing on workflow, management challenges, grant funding, assessment, and the role of serendipity. By providing a detailed case study of the Dory Project, we hope to foreground common themes likely to be experienced in other partnerships that utilize strategic collaboration.

\section{Project Partners}

Intra-institutional collaboration on the Dory Project came from four distinct Linfield College entities: the two academic disciplines housed in the Department of Theatre and Communication Arts, the Jereld R. Nicholson Library, and the Linfield Center for the Northwest (LCN). The collaboration is indicative of the institution's calling to connect learning, life, and community. The Department of Theatre and Communication Arts, as one aspect of its mission, "contributes to the broader community through its public performances, participation in professional associations, and engagement with local, regional, and global organizations" (Linfield College, Department of Theatre and Communication Arts, 2011). The Dory Project facilitates the library's vision to "build effective working relationships with Linfield faculty and staff so that the library sustains deep connections with the teaching and learning environment at the college" (Linfield College, Linfield Libraries, n.d.). The collaboration also furthers the LCN's objective to "promote field experiences and collaborative research projects that are oriented toward issues in the Pacific Northwest or that have regional implications and/or applications" (Linfield College, Linfield Center for the Northwest, n.d.).

The Dory Project also involved inter-institutional collaboration with two geographically distant 501(c)(3) nonprofit organizations: the Pacific City Arts Association (PCAA) and the Pacific City Dorymen's Association (PCDA). The mission of PCAA is to "enrich the artistic and cultural life of the Nestucca Valley, focusing on the village of Pacific City. To this end the PCAA seeks to develop, coordinate and schedule artistic, cultural and educational activities" (Pacific City Arts Association, 2007, p. 1). The PCDA's mission is to protect, defend, and promote the traditional cultural and economic values of the dory fleet. One of PCDA's five specific objectives is to "establish and support projects and events that promote the traditional, cultural, historic and educational values of the dory fleet" (Pacific City Dorymen's Association, 2012b). In addition to Linfield's community engagement with PCAA and PCDA, the Dory Project facilitated a partnership between these two local entities, which on the surface may seem to have little in common other than geography. Involvement in this venture contributed to the 
two organizations' recognition of their intersecting missions of promoting cultural and educational activities pertinent to the community.

\section{Project Goals}

The Dory Project's principal goal was to create an open-access digital historical archive for the dory fishing fleet. Housed within DigitalCommons@Linfield, Linfield College's institutional repository, the project establishes documentation of the fleet's legacy within state history. In addition to establishing the digital collections for current and future disciplinary and interdisciplinary research by scholars in communication, sociology, anthropology, history, environmental studies, and economics, project goals included:

- the creation of an original ethnotheatre ${ }^{1}$ production;

- a traveling poster exhibit to provide information about the history of the dory fleet and the research project;

- faculty presentations and publications describing the results of the research and the collaborative process; and

- student research presentations at Linfield College's annual Student Collaborative Research and Creative Projects Symposium and regional conferences.

\section{Coordination, Cooperation, and Strategic Collaboration}

Giesecke (2012), referencing organizational models within the management literature and the work of Montiel-Overall (2005), draws a distinction among coordination, cooperation, and collaboration. Coordination, the least integrated of the three models, focuses on working together to realize efficiencies. In this model, participants remain relatively independent. Cooperation involves a higher level of interaction from participants, often with the goal of working towards a common good, and agreements may be more formally articulated than in coordinated efforts. Collaboration, characterized by the sharing of expertise and ideas and a joint approach to problem-solving or enterprise creation, involves an even greater commitment from participants; according to Giesecke, it is the basis for forming partnerships. Hernas and Karas (2008) support this notion and call attention to the potential mutual benefits that can be realized from partnerships. While these distinctions may be useful among management theorists, we reject the trichotomy these definitions present and contend that, in practice, the differences among these concepts are relatively insignificant. Furthermore, collaboration among multiple entities and individuals often requires both coordination and cooperation as defined above. As such, we assign no specific meaning to each of these terms and use them interchangeably within this chapter.

In order for partnerships to be successful, participants must not only work together - they must collaborate strategically. We believe that strategic collaboration moves beyond collaboration for collaboration's sake or collaboration to solve an immediate problem. In our view, strategic collaboration involves intentionality; it represents an attempt to make purposeful connections with partners, connections that will not only enhance the services that are delivered but that will also advance the institutional missions behind those services.

${ }^{1}$ Ethnotheatre uses traditional theatre production techniques to create a "live performance of research participants' experiences and/or the researcher's interpretations of data" (Saldaña, 2005, p. 1). The script (sometimes known as an ethnodrama) draws from interviews, field notes, and artifacts gathered during the research process. Ethnotheatre, which may combine both elements of fiction and non-fiction, provides an alternative, credible form for documenting the study of individuals and their communities. 
Examples of inter-institutional collaborations within and across library types abound within the library literature. Collaborations between academic libraries are both varied and well documented, including discussion of consortial demand-driven acquisitions (McElroy \& Hinken, 2011), digitization projects (Johnson \& Mandity, 2010), cooperative collection development (Alberico, 2002; Hightower \& Soete, 1995; and Seiden, Pumroy, Medeiros, Morrison, \& Luther, 2002), and information literacy (Hope \& Peterson, 2008). There is also no shortage of articles documenting collaborations between academic and public libraries (see, for instance, Halverson \& Plotas, 2006; Hoffman, Downey, \& Sears, 2009; and Mathson, Sabo, \& Salisbury, 2009). However, academic library and special library collaborations are less prevalent in the library literature (see Carle \& Braund-Allen, 2003; Sadongei, Graham, \& Helm, 2009; and Voge, 1998), as are partnerships between academic libraries and community service or cultural organizations (refer to Adaryukov, 2004; Brinkman \& Yates, 2008; and Cook, Tennent, \& Bauer, 2011). Beyond inter-institutional collaborations, the library literature includes examples of intrainstitutional collaborations (see Dewey, 2004; Estlund, Hierholzer, \& Simic, 2010; Gaetz, 2009; Gilman \& Kunkel, 2010; and Hernas \& Karas, 2008).

As Curry (2005/2006) states, "Collaborative endeavors require a high level of leadership, a way of thinking that embraces diversity, openness to possibilities, acceptance of different perspectives, and the goal of seeking commonalities" (p. 28). These theoretical orientations and characteristics create a fertile environment in which to make decisions that will advance the goals of the collaboration strategically. While theoretical orientations are important in collaborative endeavors, equally important are practical considerations. Langley, Gray, and Vaughan (2006) highlight the need to consider a pragmatic approach to collaboration: "So much of the work in collaborative projects involves figuring out how the work will get done and then how it will travel across formal boundaries" (p. 7). Langley et al. (2006), along with Etuk and Bridges (2009), believe a number of characteristics contribute to successful collaborations: flexibility, strong networking skills, competence, openness, technical knowledge, supervisory support/freedom to pursue the collaboration, knowledge of mutual goals and long-range plans for the project, physical and virtual space in which to collaborate effectively, and marketing strategies.

Collaborative projects are excellent ways for libraries to engage with their local communities. Collaborative partnerships provide new opportunities for civic engagement, for through them libraries can provide full and free access to information, assistance in assessing that information, and a chance to participate in conversations and decision-making about common community concerns (Gaetz, 2009; Kranich, 2005/2006). Collaborative digitization initiatives can act as important gateways between academic libraries and local communities. Cooperative partnerships allow each institution to broaden its potential audience and preserve cultural history by offering access to previously hidden collections. Such initiative puts those institutions in "an unprecedented position to market their unique collections to the community and world beyond" (Spang \& Yee, 2009, p. 113). Librarians are taking a leading role in building and maintaining institutional repositories that expose those hidden collections, resulting in additional collaborative opportunities, as well as the ability to expand the dissemination of multidisciplinary scholarship (Dewey, 2004).

Collaborative projects also provide benefits for the communities they serve. Halverson and Plotas (2006) point out that one of the primary benefits from their academic/public partnership has been the recognition of the "in kind" service that the collaboration provides; this connection to the community generates good will on both sides of the partnership. Shepherd 
(2004) reminds us that local need does not disappear in collaborations; rather, partners must remember that local identities and local cultures need to be "respected and enhanced" (p. 7). Addressing this concern to the satisfaction of all parties can be difficult.

While collaboration is at the practical crux of the Dory Project, the multi-faceted paradigm of ethnography provides the theoretical grounding for both the research and artistic components. Specifically, the ethnography of communication employs ethnographic methods (such as in-depth interviews and oral histories) in order to examine and ultimately make sense of communication patterns from both individuals and communities (Cameron, 2001; Littlejohn \& Foss, 2005). Both research method and product, oral histories have traditionally illuminated the voices of individuals outside the dominant power structure (Abrams, 2010), and the stories generated by those individuals serve to collectively narrate the history of that community. Interviewees are subjects with agency who partner with interviewers in a collaborative process to "construct memory, meaning, and experience together" (Madison, 2005, p. 25).

This chapter adds to the disciplinary scholarship in several ways. First, there is very little in the library literature that addresses academic institutions partnering with geographically distant community organizations. Although Todaro (2005) and Tucker (2009) note that academic libraries are moving beyond the campus to partner with organizations in multiple ways, their discussions do not highlight partnerships beyond the local community. This chapter seeks to address that gap. Second, the complexity of collaborative partnerships within the Dory Project makes it a good case study for examining both intra- and inter-institutional collaboration. Third, this chapter helps to encourage and cultivate an "academic co-creator model for scholarship and scholarly communication where students, faculty, and librarians are all co-creators of the research and learning process" (Dewey, 2004, p. 15). Finally, this chapter attempts to identify a philosophy of strategic collaboration that could be useful to other organizations seeking to engage in collaborative partnerships.

\section{Project Description \& Chronology}

Envisioned as a two-year project that began collecting data in the summer of 2011, the Dory Project focused on the historical and contemporary role of dory fishers and dories (originally double-ended, flat-bottomed fishing boats) in the life of the coastal village of Pacific City, Oregon. A small, unincorporated village on the central coast of Oregon, Pacific City is 51 miles west of McMinnville, the home of Linfield College. Pacific City fishermen and women have launched dories through the surf at Cape Kiwanda since the early 1900s. Although major commercial fishing from the dories has given way to more recreational activity, the ways of the dory fishers remain an integral part of the traditional lore and contemporary life of the community for residents and tourists alike. As Rissel and Noegel (2010) note, "Cape Kiwanda is the only place on the West Coast where hundreds of dories are launched through the surf" (p. 69). Unlike other marine fisheries worldwide, and with similar fisheries declining or disappearing (Pacific City Dorymen's Association, 2012a), Pacific City has arguably "the largest beach fishing operation in the world" (P. Hanneman, personal communication, January 17, 2012). The Blessing of the Fleet and Dory Days events lure hundreds of people to Pacific City and Cape Kiwanda each summer.

Prior to the Dory Project, there had been no large-scale effort to document the history of the Pacific City Dory Fleet. The most complete historical study of both river and ocean commercial salmon fishing focused on the work of only seven fishermen (Taylor, 1990, 1991). Consequently, the history of the fleet endured through individuals' tales and the collective recounting of innumerable personal experiences that, until the Dory Project, had not been 
systematically recorded. Drawing inspiration from the words of noted historian Gerda Lerner (1997), who stated, "We live our lives; we tell our stories. . . The past becomes part of our present and thereby part of our future" (p. 211), the Dory Project aims to tell the stories of the fleet from the perspectives of those who know it best. Given social, environmental, and economic changes affecting the Pacific City fishery, the continued existence of the dory fleet is not a given. Longtime members of the PCDA suggest that access to the fleet's history could help perpetuate the fleet's existence because its history is so entwined in the history of the state of Oregon (D. Larkins, personal communication, January 17, 2012).

The impetus for the Dory Project came from the project director, who was chair of the Department of Theatre and Communication Arts at Linfield and a board member of PCAA. In the late summer of 2010, PCAA started to look for ways to highlight the cultural tradition aspect of its mission. The phrase "Pacific City-Home of the Dory Fleet," seen on road signs approaching Pacific City, presented an "a-ha" moment. In her role as chair, the project director had sought opportunities for the two distinct disciplines to find points of intersection for collaboration among faculty members, as well as among students from its three majors. The project director had also contemplated departmental projects that would directly correlate with Linfield's newly created core themes focusing on engagement, integrated teaching and learning, experiential learning, and multicultural understanding. These various strands came together in a "perfect web" as the idea of a project focused on the Pacific City Dory Fleet took shape. The Dory Project took place in three phases - phase zero/project development (fall 2010 through late spring 2011), phase one (summer 2011, with some work continuing through early spring 2012), and phase two (summer 2012 through spring 2013).

\section{Project Chronology: Phase Zero}

As indicated earlier in this chapter, successful project management requires a number of different skills, including leadership, flexibility, and openness to possibilities. On a very practical level, it also requires a high degree of organization, attention to detail, and the ability to multitask. All of these skills were essential for the planning that took place in phase zero. Early in this stage, the project director secured participation from colleagues in the department. Two of the other three full-time faculty members in the Department of Theatre and Communication Arts agreed to join the project in phase one and serve as faculty designer and faculty playwright. Once department colleagues approved the venture, the project director began discussions with PCAA. Many PCAA members had either grown up in the area or had lived in Pacific City for a number of years. Each was supportive of exploring this aspect of their local history and culture and enthusiastically endorsed the project. There were no hurdles involved in forming this collegecommunity partnership, in part because the project director and faculty designer were involved in the creation of the association and had served on the PCAA board since its inception. Thus, the personal trust and collegiality that had developed over a period of three years transferred to the proposed partnership.

Simultaneously, the project director began talking with a friend, who was a long-time dory fisherman and member of PCDA, to gauge potential interest from this essential community partner. He was excited about the project and agreed to contact one of the co-chairs of PCDA to explore the idea. While the friend was relatively certain PCDA would join the effort, it was clear that the development of this partnership would be more difficult. Because of challenges such as regulatory restrictions, members of the dory fleet understandably want to protect their access to the beach and fishing rights. They often view outsiders with some degree of suspicion and are concerned about possible hidden agendas that might harm the fleet. Due in large part to the 
efforts of the friend who served as an unofficial liaison between the project director and PCDA, the PCDA co-chair cautiously signaled that he and PCDA would be interested in pursuing the project.

While exploring partnership options with the Pacific City organizations, the project director initiated conversations with the director of Linfield's libraries and the institutional repository (IR) librarian. Obviously, collecting oral history interviews and artifacts required a mechanism for storing the data and providing access to it. Since members of the dory community were not interested in permanently donating their memorabilia to a collection housed outside the local community, creating a digital collection was the logical solution.

DigitalCommons@Linfield would permit the inclusion of audio and video stories derived from the oral histories, as well as digitized versions of various artifacts. The repository would also facilitate widespread open access to the collection through the Internet. Both librarians welcomed the opportunity for the library to participate as a project partner, further strengthening existing collaborative relationships between the two departments.

In January 2011, with all of the partners in place, the project director submitted a formal overview of the project to the collaborators. It included an outline of contributions each of the entities would make to the project. The document also noted the intent to apply for grants (further detail below) to provide the financial resources for the first phase of the project. In May 2011 , once grants had been secured, the director contacted all of the collaborators, detailing again the goals of the project, expectations for each of the partners, and a tentative timeline for the summer's activities. The co-chair of PCDA then communicated information about the project to the full membership. The co-chair also indicated that the person who had initially served as the unofficial liaison would continue in that official role between PCDA and the Linfield team.

Grants. Linfield College supports two faculty-student collaborative research grant programs. In February 2011, the project director and two students successfully applied for a $\$ 10,000$ Community Engaged Research to the Classroom (CERC) Summer Collaborative Research Grant through the LCN. The faculty designer and faculty playwright each successfully applied with one student for Faculty-Student Summer Collaborative Research Grants (worth $\$ 3,000$ apiece) through the Faculty Development Program sponsored by the Office of Academic Affairs. Each of these grants provided a stipend and housing for students, enabling them to devote time to the project while earning money for the following school year. All grants also included a small stipend for faculty. Additionally, the LCN funding incorporated monies for equipment, supplies, and transportation. Student collaborators for all grants were selected based on skills they could contribute, a known capacity for working as team members, and perceived interest in devoting a summer to the research project. As part of this and future grant-writing processes, the Dory Project researchers anticipated the following benefits for stakeholders:

- Researchers - As a result of the various scholarly and creative products stemming from the Dory Project, the professional visibility of Linfield faculty and students would be increased.

- Cultural organization collaborators (PCAA and PCDA) - As a result of this project, PCAA (a relatively new organization) would be able to develop more visibility within the community and demonstrate the role the arts can play in preserving and promoting historical and cultural traditions. Likewise, this project would assist PCDA in its efforts to preserve personal memories and artifacts and to create a collective history of the dory fleet. The Dory Project would provide a means for PCAA and PCDA to forge links 
throughout the community, strengthening not only support for the dory traditions but also for the arts.

- Linfield College - As a result of the vast network of personal and professional relationships forged during the project, Linfield College would be able to develop a positive "town and gown" relationship with a regional community outside McMinnville. Additionally, by documenting and interpreting an important way of life and cultural treasure unique to the Oregon coast, and by helping to preserve and provide access to primary resources about the Pacific City Dory Fleet, this project would enhance Linfield's reputation as an institution that is committed to providing students with highimpact experiential learning opportunities within the region.

- Residents of Pacific City and other Oregon communities - As a result of the digital archives available open access through DigitalCommons@Linfield, the Dory Project would contribute to the cultural life of residents in Pacific City and greater Tillamook County, throughout the state of Oregon, and beyond.

While this list of benefits was not intended to be exhaustive, identifying the primary stakeholders and the perceived benefits to each group was an essential first step in knowing what to assess to determine the success of the project. Similarly, knowing that many collaborations struggle because of communication, control, trust, equity, and resource issues ${ }^{2}$ enabled the research team to proactively counteract these potential barriers.

Practical/Technical Considerations. Because the research team was conducting interviews, the project director discussed the project with the chair of Linfield's Institutional Review Board (IRB). The IRB determined the Dory Project did not need to be submitted for formal review. Prior to moving into phase one, however, potential interviewees (referred to as storytellers) needed to be identified. The PCDA liaison was instrumental in this regard and played a major role in establishing credibility and securing good will for the project. He called more than fifty individuals to explain the project and to solicit their participation, and only one declined to participate. As the project continued, the PCDA liaison added names to the list. During interviews, storytellers often suggested additional people to contact. As news of the venture spread, individuals began to call or email the project director to offer their stories, names of people they deemed important to the project, and their personal artifacts for digitizing. Even with the endorsement and collaboration of PCDA at the organizational level, without the PCDA liaison it would have been difficult to gain the trust of individuals within the dory community.

Beyond identifying storytellers, the researchers needed to acquire equipment for recording the interviews. After considering the need to balance quality with costs, redundancy in case of equipment failure, and flexibility when in the field, the following items were purchased through a combination of grant and departmental funds:

- video cameras (standard (2) and point-and-shoot) and tripod;

- digital audio recorders (4);

- wireless microphone system with 2 mics;

- scanners (large format and standard size); and

- external hard drives (4) and multiple SD cards.

With the community partners and the research team in place, and with equipment secured, the focus shifted to how the collected data would be presented in the repository.

\footnotetext{
${ }^{2}$ For example, refer to Doyle, Millson-Martula, and Stratton, 2003; Francisco, Hannah, Keller, Waters, and Wong, 2001; Hightower and Soete, 1995; and Seiden et al., 2002.
} 
Through a series of meetings, the project director and IR librarian talked through the kinds of raw data that would be collected, the content that would likely be produced during the project, and how future researchers might use that content. The repository already had a set of digitization standards in place (Linfield College, DigitalCommons@Linfield, 2011), outlining the minimum requirements for digitization, recommended and acceptable file formats, basic information on image adjustment and the use of watermarks, and file naming conventions. General metadata entry guidelines (Linfield College, DigitalCommons@Linfield, n.d.) had also been developed for the repository, to be used by content creators when providing descriptive metadata to the IR librarian. These documents provided good starting points for conversations with the research team.

For repository software, Linfield College uses bepress’s Digital Commons ${ }^{\circledR}$ platform, a hosted service that employs the Dublin Core metadata schema. Before any kind of arrangement for the Dory Project content could be determined, it was necessary for the research team to understand the back-end architecture of how collections were organized in the repository. The IR librarian met with the three faculty researchers for an informational session to explain the platform-specific architecture, and she discussed the notion of relating resources across the collections. She also presented a provisional collection arrangement at that meeting, which was subsequently modified and expanded.

Once the basic architecture for the project was agreed upon, the IR librarian worked with the project director to tailor the metadata elements that would be used with each collection. Although the Digital Commons ${ }^{\circledR}$ platform uses a default set of metadata elements for new collections, this is entirely customizable. For example, the project director wanted to be able to include a set of acknowledgment statements with each metadata record to give credit to the various entities who were helping to support the project; however, she did not want this to be included as part of the abstract or item description for each record. As a solution, the IR librarian employed the Comments field (which maps to dc:description rather than the more specific dc:description.abstract) to include this information.

After the metadata element set was finalized, the IR librarian initiated the build of the structure and created wikis to house the processing guidelines for each collection. (The wikis, in conjunction with the element set mappings to Dublin Core, essentially constituted application profiles for each collection.) Beyond creating documentation to aid in student processing of the collections, the IR librarian offered recommendations for file naming conventions to the project director, who developed a cheat sheet for the researchers to use to ensure consistency in naming. As new types of artifacts were digitized, the file naming conventions were updated.

Other technical considerations arose during the latter stages of phase zero. The researchers knew they would be capturing oral history interviews on both audio and video. However, Linfield does not have a streaming media solution in place; this meant that, until a streaming solution was available, whatever content was uploaded to the repository would need to be small enough in file size to be easily downloaded by a variety of Internet connections. In addition to the file size issue, the researchers needed to establish guidelines related to inclusion of copyrighted materials (such as newspaper and magazine articles, or videos) that were a part of personal collections. The IR librarian researched the issue and, after multiple conversations with the project director, recommended that copyrighted materials should not be included in the digital archives. However, because the copyrighted materials would be essential to the creation of the ethnodrama, the researchers determined the copyrighted materials could still be scanned for personal use by the faculty and students, in accordance with fair use. 
The final major hurdle in project development prior to collection of data involved the creation of a set of permissions documents. The IR librarian provided several examples of permissions documents to the project director, including a deed of gift form, which the project director then adapted and shared with the other researchers. Because the researchers anticipated interviewees would make varied types of contributions to the project, the team ultimately used three forms - an artifact release form/deed of trust (which granted permission to digitize any personal artifacts, enabled the Linfield Libraries to keep a copy of the digital surrogates, and transferred copyright of the digital surrogates to Linfield), a recording and photograph release form (which allowed the oral history interview to be recorded/photographed and set forth any restrictions on personal identification of the interviewee), and a participant information form (to assist in further contact with interviewees). Once final versions were agreed upon, the researchers were ready to proceed with data collection. Ten months after the initial serendipitous "a-ha" moment gave birth to the idea, it was finally time to launch phase one.

\section{Project Chronology: Phase One}

In addition to the faculty, four student researchers representing majors in communication arts, education, and theatre participated in the Dory Project during phase one. The faculty designer and the faculty playwright shared responsibility for video and audio equipment for the interviews. The faculty designer also served as the team photographer and supervised digitization of artifacts. The faculty playwright and the project director shared oversight of the interviewing process. The project director became the liaison to all the partner organizations, negotiated the scheduling of interviews, and coordinated the management of data and personnel. The IR librarian voluntarily assisted with fieldwork during this phase. One of the students worked primarily with the recording equipment and was the lead person for scanning and indexing artifacts. The other three students took turns serving as interviewers and note takers. Student and faculty researchers were all cross-trained and available to complete any of the various small and sometimes unanticipated tasks that arose during the course of the project, although there was less crossover work than initially envisioned.

The first venture into the field occurred at the beginning of June 2011 when the entire group attended the Blessing of the Fleet. For most of the research team, this was the first encounter with the dory community. Prior to the event, students and faculty discussed short readings about the history of Pacific City and Cape Kiwanda, as well as a collection of brief documents about the dory fleet. Through a series of articles about ethnography, ethnotheatre, oral history, and research with human subjects, the researchers developed an understanding of the theoretical underpinnings, methodological procedures, and ethical considerations that grounded the project. The project director shared insights gleaned from conversations with the PCDA liaison. During the ceremony, team members were asked to listen for significant themes in the discourse and to reflect upon what they heard. Following the Blessing, the faculty and student researchers gathered to discuss the event and to develop a series of interview questions grounded in the discourse they had heard and read. This exercise engaged the student researchers and gave them a sense of ownership of the project. The researchers also developed questions for use in brief on-the-spot interviews. Once the interview questions had been refined, the researchers conducted several mock interviews to practice equipment setup and use, as well as interviewing techniques. The researchers practiced listening techniques and follow-up questioning to develop the skills and flexibility necessary to conduct an in-depth interview in which the interviewees could tell their stories without interruptions. 
During phase one, the researchers conducted in-depth structured audio and video interviews with 37 individuals. Researchers made the decision to follow the ethnographic approach and "go to the people." Rather than using a central location within the community for an interviewing studio, the team went to the homes or businesses of the storytellers. The researchers conducted interviews in kitchens, living rooms, garages, barns, in backyards, and on decks. While the recording quality was not as pristine as it might have been in a controlled environment, the location contributed to the authenticity of the interviews. The familiar location also helped put the interviewees at ease. As a bonus, the interviews often included tours of boat shops or related areas. The team interviewed fathers and sons, fathers and daughters, husbands and wives, and fishing buddies together. Interview length was unpredictable, ranging from one to four hours; as such, the project director always had to factor this in to the schedule.

The research team conducted loosely structured on-the-spot interviews (lasting 10 to 15 minutes) with an additional 18 people during Dory Days. The purpose of the on-the spot interviews was to elicit comments from parade participants, regular festival goers, and tourists to collect their thoughts about the dory fleet and its role in the community. One serendipitous outcome of the short interviews was the opportunity to interview dory fishers who had not appeared on the list of potential storytellers. Often the brief interviews led to full-length, formal ones.

Given its scope, the Dory Project generated a large volume of data. In addition to the interviews conducted during phase one, the team scanned nearly 700 artifacts and launched the digital archives via DigitalCommons@Linfield. Although the project director and her colleagues had developed plans for managing the materials, flexibility was required to adjust to both changing conditions and the learning curve associated with launching a multi-faceted research program. The following description of the general workflow illustrates the complexity of managing the project.

General Workflow. Although the drive from McMinnville to Pacific City is only 102 miles round trip, it became clear that daily driving back and forth would not be an effective use of resources. During most weeks, field interviews occurred on two or three back-to-back days. This meant the project director needed to coordinate transportation, lodging, and meal planning, lending an aura of summer camp to the fieldwork experience. PCAA board members (including the project director and faculty designer) agreed to provide housing as needed as part of their contributions to the project.

Once the researchers reached the interview destination, the project director met with the interviewees to review the permissions documents and obtain the appropriate signatures. (Upon return to campus, copies of the release forms were made for the project files and for mailing to the interviewees; the originals were then transferred to the IR librarian.) Researchers then conducted the interview.

As soon as possible following an interview, raw video and audio footage was downloaded from the SD cards used for recording. This step frequently occurred in the field. Materials were downloaded to a laptop or external hard drive, named according to the established conventions, and then copied to a backup external hard drive. Because most of the research team used Apple computers, converter software was required for the initial download of most video files. Files downloaded in real time, often a lengthy process.

For permanent storage of raw data and all edited files, the project used CatFiles, one of the college's shared file storage solutions. Once the researchers retuned to campus, the raw data files were uploaded to CatFiles. (Due to limitations of wireless connections and large file sizes, 
upload from the field was not possible.) The project director managed the final backing up of data and developed a hierarchy of folders to house the various files as they moved through multiple stages of review.

After data was backed up, the raw audio files were mapped so the researchers would quickly be able to find particular stories or themes during the editing stage. ${ }^{3}$ Once mapping was completed, editing began. ${ }^{4}$ Edited stories were reviewed and returned to the student for any revisions. Once the edited stories were approved, they were moved to a folder in CatFiles for transcription. ${ }^{5}$ When the initial transcript was complete, the file was moved to another folder to await a second review.

Given the large number of storyteller photos taken at each interview and the volume of other photos, the faculty designer maintained the raw photo files, originals, and backup copies on individual external hard drives. Photographs selected for inclusion in the repository were transferred in both TIFF and JPEG format to the project director or a student researcher for metadata creation.

When interviews were scheduled, storytellers were asked if they had memorabilia they would be willing to have scanned for the digital collections. In most cases, materials were collected at the interview, although in some cases they were transferred to the project director at another time. Whenever possible, artifacts were scanned in the field. When artifact size or volume of materials did not allow scanning to be completed in the field, items were brought to campus and scanned there. Hard copies were made of each scan to facilitate use by the production designers. Once artifacts were scanned, the project director returned the personal collections to the interviewees.

Throughout the process, the project director tracked the movement of all materials using Excel spreadsheets. Uploading of raw data files and permissions forms were tracked in one form, assignment of story editing and transcription in another. Once stories and transcripts were created and in draft mode, they were tracked through the process using a color-coding system. As edited stories, transcripts, photographs, and metadata forms were finalized, they were moved to a specific folder in CatFiles. The IR librarian then took over management of the files and supervised ingest of archival masters and access copies into the repository, assisted by a digital repository assistant. ${ }^{6}$ After materials had been made live, related resources were linked to one another; a color-coded wiki was created to track these intricate relationships, which became

\footnotetext{
${ }^{3}$ Although mapping began during phase one, it became clear at the beginning of phase two that mapping should be a higher priority, particularly in the face of the impending work on the ethnotheatre script. Therefore, during phase two all student researchers participated in mapping interviews from both phases of the project to facilitate the playwrights' work.

${ }^{4}$ The researchers started with audio stories because they were quicker to edit and because a streaming media solution was still not in place. To expedite editing in phase two, one student with experience in sound design completed most of the audio editing. Video editing also began in phase two.

${ }^{5}$ Because of the intense interview schedule, very little transcription work was completed in phase one.

${ }^{6}$ During phase one, a student worker unaffiliated with the Dory Project uploaded content into the repository. Unlike the student researcher in phase two, this student worker was responsible for uploading content only, not for creating metadata.
} 
increasingly complex as the number of items in the collections grew. Once materials were live, the files in CatFiles were moved one final time to a folder containing all the uploaded content.

Although there were some exceptions, the team members worked similar schedules whether they were on campus or traveling. Coordination of the researchers' schedules was fairly painless most of the time and took advantage of the students' proclivity for texting. The primary work in phase one concluded in August 2011. In order to continue the development of materials for the digital collections, three of the students enrolled in independent study courses facilitated by the project director during the 2011-2012 academic year. They continued editing and transcribing audio stories. The fourth student volunteered to continue scanning photographs and other documents. With the exception of one student who was studying abroad, the researchers ventured into the field again in January 2012 to interview the last remaining dory builder in Pacific City. During this "quiet" phase, the project director provided updates to the community partners and worked with various campus offices to facilitate planning for the second phase of the project, including additional grant funding.

Grants. In March 2012, the faculty designer and two students successfully applied for a second CERC Summer Collaborative Research Grant through the LCN, worth $\$ 8,820$. The project director, faculty director, and the IR librarian jointly applied for a Faculty-Student Summer Collaborative Research Grant totaling \$10,939 through the Faculty Development Program sponsored by the Office of Academic Affairs. As in the previous year, this funding provided a stipend and housing for the student researchers, in addition to a small stipend for faculty. The LCN funding was used for equipment, supplies, transportation, stipends and housing for the students, and a small stipend for the faculty designer.

In partnership with PCAA and PCDA, external grants were also sought. This required an additional level of coordination with the two community organizations, collaborative work with the college's grant writer, and cooperation from the faculty researchers in order to allow sufficient time to prepare materials and meet external deadlines. The project director successfully applied for a \$3,500 Arts Build Communities grant from the Oregon Arts Commission, which provided support for scriptwriting and multimedia design concept development for the theatrical production. Two applications went unfunded: a $\$ 2,900$ request from the Oregon Council for the Humanities to support visiting scholars for two post-show guided discussions, and an $\$ 8,597$ request from the Oregon Heritage Commission for equipment and student stipends to continue editing audio and video stories and digitizing artifacts.

\section{Project Chronology: Phase Two}

The summer of 2012 ushered in phase two, which saw some changes in the research team. The fourth faculty member from the Department of Theatre and Communication Arts (who served as director for the ethnotheatre production) joined the team. The IR librarian also joined the team in an official capacity, along with five new and two returning student researchers representing majors in communication arts, creative writing, education, mass communication, philosophy, and theatre. In addition to ongoing data collection and processing in phase two, the project director continued to focus on managing resource challenges, and the researchers initiated assessment efforts. Researchers collected artifacts and in-depth oral histories from an additional 42 individuals, conducted another 44 on-the-spot interviews during the Blessing of the Fleet and Dory Days, and continued development of the digital collections. Audio and video editing, transcription, and digitization of material from both project phases took place during phase two, as did pre-production preparations for the ethnotheatre production (which occurred in November 2012). The researchers planned to continue data collection by conducting a small number of 
interviews through spring 2013, and they planned to continue processing materials for the archives indefinitely, as time and resources permitted. ${ }^{7}$

Managing Resource Challenges. In phase two, coordination of personnel grew even more complicated due to both the increased number of researchers and more specific task assignments. While efforts were made to have full participation from both student and faculty researchers in all major aspects of the project, schedules sometimes precluded this from happening. The researchers needed to work around other position responsibilities (particularly for the project director and IR librarian), vacations, and part-time jobs (since the student stipends amounted to less than 40 hours per week). Similarly, schedules occasionally needed to be adjusted to coordinate with promotional events on campus in which the Dory Project was featured, particularly those involving the College Relations office. ${ }^{8}$ The project director also had to coordinate payroll with multiple offices rather than a single entity.

Given the relatively large size of the research team, along with the interconnectedness of the project, it was inevitable that bottlenecks would occur en route to making some of the materials available through the repository. The IR librarian could not upload content until it was ready, and because it took different lengths of time to prepare materials, upload of content was sometimes delayed. Although students could devote significant amounts of time to the project during the grant-funded periods, progress slowed once the funding ran out. Even those students who continued to work on the project for independent study credit could not devote the same amount of time as they had previously. The project director emphasized more intentional crosstraining for the student researchers during phase two as a way to try to pre-empt the bottleneck effect, but, even though delays were not as severe, cross-training did not entirely eradicate the problem.

Management of the interview process also required planning, flexibility, patience, and reliance on serendipitous good fortune. While a number of the storytellers were retired, many still worked. Some lived in Pacific City or the surrounding area full-time; others only came to the coast on weekends or for vacations. Most importantly, the interviews could not get in the way of fishing. Although contemporary technology assists fishers in planning, ocean conditions at any given moment ultimately determine whether or not they can launch through the surf. Likewise, the duration of a fishing trip depends on fishing conditions. It was not uncommon to receive a phone call from a fisher on the ocean asking to adjust the interview time. When cancellations occurred, the project director attempted to contact other potential interviewees to try to fill the slot. Many times this approach worked, resulting in only limited loss of interview time. One example in particular merits discussion.

On one morning, the group was on the beach to record video and audio for potential use in the theatre production when the project director learned an afternoon interview had been

\footnotetext{
${ }^{7}$ In October 2012, the project director and faculty designer submitted sabbatical applications to continue work on the Dory Project during spring 2014.

8 The College Relations office is responsible for promoting Linfield to external media outlets. The project director coordinated publicity efforts with the director and assistant director of communications and the director of media relations. These individuals met with the entire research team on several occasions and participated in numerous meetings, phone calls, and email correspondence in an effort to help promote the project to a wider audience. PCAA and PCDA also partnered with the local media to facilitate publicity efforts on behalf of the Dory Project.
} 
cancelled. At the same time, two fishermen landed on the beach. When the project director approached them and identified herself, one commented that he had heard about the project and would like to be interviewed. She asked if he would be available that afternoon. He indicated it would take them a few hours to clean the boat and equipment and take care of the fish but that they could probably do the interview late in the afternoon. The project director asked if the team could record them as they did these tasks, and the fishermen agreed, so the team followed the fishermen home. Four to five hours later, the researchers had learned such intricacies as cleaning equipment, cooking crab, identifying fish, and filleting them. The demonstration and formal interview that followed provided invaluable information for the research team, as well as unique audio and video footage. This incident was a prime example of how serendipity augmented careful planning in the research process.

Grants. During the fall of 2012, the project director applied for a \$2000 grant from the Yamhill County Cultural Coalition to support construction of the traveling poster exhibit. Featuring panels describing the history of the dory fleet, the exhibit will be displayed at public libraries, community centers, cultural and heritage centers, and museums throughout the state of Oregon. (Note to editors: This grant is pending, but we should receive a decision by the end of November.)

Assessment. One of the challenges of collaborative partnerships can be how to assess their success. Kaufman (2012) admits that measuring the value of a collaboration is difficult, particularly when trying to assess "soft" measures. Holt, Holt, and Lloyd (2006) acknowledge that successful partnerships require good planning, adequate resources, regular communication, and a commitment from all participants to ensure the project's success (p. 98). Similarly, partner institutions need to make clear any expectations they might have about what they are able to contribute to the collaboration, as well as what they hope to receive from their participation in it (Holt et al., 2006). Shepherd (2004) reminds participants that, in addition to economic benefits, collaborators may also receive informational, educational, cultural, and social benefits.

The research team utilized a variety of methods to assess the success of the Dory Project. Statistics on usage of the repository content are gathered from reports provided by the software provider, as well as from Google Analytics. As this chapter went to press, the digital collections had received visitors from 29 states and 24 countries. Materials had been viewed or downloaded more than 8,200 times.

Success was also measured in terms of practical skills gained by the student researchers. Students who began the project with technical skills in editing, digitization, interviewing, and so forth certainly improved those skills over the length of the project. However, several students did not have prior background in using particular software applications (for instance, Final Cut Pro, Adobe ${ }^{\circledR}$ Photoshop ${ }^{\circledR}$, Audacity ${ }^{\circledR}$, or the Digital Commons ${ }^{\mathrm{TM}}$ repository platform). By the time they completed their grants, students had successfully learned to navigate these programs and had gained "hard" skills that would continue to serve them in future courses and employment opportunities. In addition, student researchers came away from the project with improved "soft" skills, primarily as a result of the highly collaborative nature of the entire project. The faculty researchers saw improvement in students' confidence when conducting interviews, an increased level of professionalism when discussing the project formally or informally, and refined critical thinking skills.

Students demonstrated their skills not only in work with faculty members but also in public fora. The four students working with the LCN grants gave professional presentations of their work as part of a noon series open to the Linfield and McMinnville communities. These 
students also participated in presentations about the project in various courses taught by the faculty collaborators. All students participated in the annual Linfield College Student Collaborative Research and Creative Projects Symposium. One of the student researchers from phase one used data from the project in her departmental capstone paper, which was presented publicly on campus. In addition, the paper was competitively selected for presentation at a Northwest Communication Association annual conference. These posters, presentations, and papers have been or will be included in DigitalCommons@Linfield, thereby contributing to the existing scholarship on the Pacific City Dory Fleet.

Other assessment tools included the evaluation of student work and a survey related to the ethnotheatre production. In reflective papers, student researchers were asked to consider the skills they had gained, the ways in which coursework had prepared them for participation in the project, and how the knowledge and skills gained through the project would assist them in future courses, as well as in potential careers. In addition, they were asked to discuss how their work on the project had contributed to the learning outcomes of their major areas of study. Using different modes of reflection, the theatrical production provided a public arena in which to evaluate the project as it brought together multiple facets of the collaborative venture. In accordance with the Oregon Arts Commission grant, the researchers assessed audience responses to the production through a survey based on a 2007 study, "Assessing the Intrinsic Impacts of a Live Performance."

\section{Launching through the Surf and Kickin' Sand and Tellin' Lies}

The three primary products of the Dory Project were the digital collections, the ethnotheatre production, and the traveling poster exhibition. Launching through the Surf: The Dory Fleet of Pacific City ${ }^{9}$ incorporates multiple collections that are cross-linked in order to lead users to related materials. For example, an audio story might link users to images of that storyteller, a transcript for the audio story, additional audio stories by the same storyteller, and any associated archival images. An audio collection contains more than 30 stories, ranging from one to four minutes in length, which can be downloaded as .mp3 files. An image gallery of storyteller photographs documents 28 of the individuals who were interviewed during phases one and two of the project. Another image gallery includes photographs of dories and related artifacts taken by the faculty designer; it will eventually include archival photos that were scanned from storytellers' personal collections. A collection of PDF transcripts provides textual access to the audio stories. (Transcripts from video stories are also planned.) Forthcoming collections include storyteller profiles that will provide biographical context for researchers, a video collection of edited footage from both in-depth and on-the-spot interviews, a digital version of the traveling poster exhibit, and a collection of related scholarship on the Dory Project from the researchers, including an annotated bibliography. When a streaming media solution is in place for the college, a full-length video of Kickin' Sand and Tellin' Lies (the ethnotheatre production) will also be part of the collections. Existing collections will continue to be augmented with new material.

\section{Conclusions}

Despite the clear benefits that can be realized from intra- and inter-institutional collaborations, many institutions are still reluctant to form such partnerships. We believe the intentionality that is inherent in strategic collaboration may help to mitigate against many of the potential barriers. Connecting collaborations with departmental or institutional missions logically requires more forethought and planning, but it is precisely this attention to purpose on the front end of a

\footnotetext{
${ }^{9}$ The digital collections can be viewed at http://digitalcommons.linfield.edu/dory/
} 
collaborative partnership that can increase the effectiveness and ultimate success of a collaboration.

This case study has demonstrated the evolution of a strategic collaboration. From its inception, the Dory Project benefitted from having a mutually agreed-upon structure that allowed all partners to understand their respective roles within the partnership. The project partners took advantage of local subject expertise and project management skills, targeted funding opportunities, and capitalized on the organizations' desire to engage in a collaboration that would advance their organizational missions. Partners emphasized frequent communication from the very early stages of the project, continuing throughout both phases of data collection. In doing so, the collaborators were able to seize serendipitous opportunities as they arose. If we measure success by adherence to the aforementioned qualities (such as leadership, openness, acceptance, looking for commonalities, maintaining a pragmatic approach to problem-solving, flexibility, networking, infrastructure support, expertise, and trust), then we have met our goals for the Dory Project.

From an ethnographic research perspective, the dory fleet of Pacific City continues to traverse the boundaries between commercial and sport fishing and between the past and the present, all the while trying to preserve its heritage. Likewise, the researchers constantly tread the line between participant and observer and between content collector and content creator. From a pedagogical perspective, the Dory Project gave the researchers an opportunity to put into practice what is most often discussed in the classroom. Student researchers participated in experiential learning opportunities in multiple venues and witnessed the benefits of strategic collaboration, gaining tools they can continue to use throughout their educational and professional lives. Through engagement in the project, faculty researchers pursued their own professional work and modeled the life of the scholar for students. Additionally, faculty members demonstrated that the root of ethnographic scholarship resides in community.

Beyond the specifics of the Dory Project, this case suggests both a widespread need and opportunity for faculty and student researchers alike to engage with other communities and cocultures with an eye toward documenting their experiences. It encourages drawing on established personal and professional relationships, both intra- and inter-institutional, as a foundation for broader collaborative efforts. While valuing careful planning and detailed organization, the project also points to the need for collaborators to embrace flexibility and serendipity. It notes the need for patience in the face of challenges that will arise in any coordinated partnership.

Lerner (1997) contends that "we experience; we give voice to that experience, others reflect on it and give it new form. That new form, in its turn, influences and shapes the way next generations experience their lives" (p. 211). If our institutions of higher learning are to continue to exist and to remain relevant, then we need to pursue strategic collaborations with communities to give voices to our collective experiences - to tell our stories. 


\section{References}

Abrams, L. (2010). Oral history theory. London, England: Routledge.

Adaryukov, A. (2004). Cooperative dimensions of a digitization project. Resource Sharing \& Information Networks, 17(1-2), 175-185.

Alberico, R. (2002). Academic library consortia in transition. In L. G. Dotolo \& J. B. Noftsinger, Jr. (Eds.), Leveraging resources through partnerships (pp. 63-72). San Francisco, CA: Jossey-Bass.

Brinkman, S., \& Yates, F. W. (2008). Promoting partnership: Campus and community collaboration through cultural events. College \& Research Libraries News, 69(3), 147150. Retrieved from http://crlnews.highwire.org/content/69/3/147.full.pdf

Cameron, D. (2001). Working with spoken discourse. London, England: Sage.

Carle, D. O., \& Braund-Allen, J. (2003). Alaska Resources Library and Information Services: Pioneering partnerships on the last frontier. Science \& Technology Libraries, 24(1-2), 107-133. doi:10.1300/J122v24n01_08

Cook, E. I., Tennent, B., \& Bauer, M. (2011). Literary homecoming as collaboration: Eastern North Carolina libraries connect with the creative sector. Collaborative Librarianship, 3(2), 79-89. Retrieved from http://collaborativelibrarianship.org/index.php/jocl/article/view/149/95

Curry, E. A. (2005/2006). Play with the Slinky®: Learning to lead collaboration through a statewide training project aimed at grants for community partnerships. In W. Miller \& R. M. Pellen (Eds.), Libraries beyond their institutions: Partnerships that work (pp. 25-48). Binghamton, NY: Haworth Information Press.

Dewey, B. (2004). The embedded librarian: Strategic campus collaborations. In W. Miller \& R. M. Pellen (Eds.), Libraries beyond their institutions: Partnerships that work (pp. 5-17). Binghamton, NY: Haworth Information Press.

Doyle, C., Millson-Martula, C., \& Stratton, S. (2003). Stone age consortia, new age consortia: The place for coordinated cooperative collection management. In K. P. Strauch (Ed.), Charleston Conference proceedings 2001 (pp. 157-167). Westport, CT: Libraries Unlimited.

Estlund, K., Hierholzer, K., \& Simic, J. (2010). Supporting faculty research through collaborative digital projects: The Mongolian Altai inventory. Collaborative Librarianship, 2(2), 51-64. Retrieved from http://collaborativelibrarianship.org/index.php/jocl/article/view/60/48

Etuk, L. E., \& Bridges, L. M. (2009). Oregon Rural Communities Explorer. In N. Courtney (Ed.), Academic library outreach: Beyond the campus walls (pp. 135-146). Westport, CT: Libraries Unlimited.

Francisco, G. B., Hannah, K. C., Keller, S. G., Waters, J., \& Wong, P. M. Y. (2001). Joint ventures: The promise, power, and performance of partnering. Sacramento, CA: California State Library.

Gaetz, I. (2009). Collaborative Librarianship: New light on a brilliant concept. Collaborative Librarianship, 1(1), 1-12. Retrieved from http://collaborativelibrarianship.org/index.php/jocl/article/view/9/1

Giesecke, J. (2012). The value of partnerships: Building new partnerships for success. Journal of Library Administration, 52(1), 36-52. doi:10.1080/01930826.2012.629964 
Gilman, I., \& Kunkel, M. (2010). From passive to pervasive: Changing perceptions of the library's role through intra-campus partnerships. Collaborative Librarianship, 2(1), $22-$ 32. Retrieved from http://collaborativelibrarianship.org/index.php/jocl/article/view/58/40

Halverson, K., \& Plotas, J. (2006). Creating and capitalizing on the town/gown relationship: An academic library and a public library form a community partnership. Journal of Academic Librarianship, 32(6), 624-629. doi:10.1016/j.acalib.2006.10.001

Hernas, P., \& Karas, T. (2008). Campus partnership in small academic libraries: Challenges and rewards. In J. M. Hurlbert (Ed.), Defining relevancy: Managing the new academic library (pp. 131-145). Westport, CT: Libraries Unlimited.

Hightower, C., \& Soete, G. (1995). The consortium as learning organization: Twelve steps to success in collaborative collections. Journal of Academic Librarianship, 21(2), 87-91.

Hoffman, S., Downey, A., \& Sears, S. (2009). Collaborating with your local public library. In N. Courtney (Ed.), Academic library outreach: Beyond the campus walls (pp. 67-75). Westport, CT: Libraries Unlimited.

Holt, L. E., Holt, G. E., \& Lloyd, S. (Eds.). (2006). Library success: A celebration of library innovation, adaptation, and problem solving. Ipswich, MA: Ebsco.

Hope, C. B., \& Peterson, C. A. (2008). The sum is greater than the parts: Cross-institutional collaboration for information literacy in academic libraries. Journal of Library Administration, 36(1-2), 21-38. doi:10.1300/J111v36n01_03

Johnson, J., \& Mandity, E. (2010). From real challenges to virtual reality: Realizing your collection through digital partnership. Computers in Libraries, 30(9), 18-22.

Kaufman, P. (2012). Let's get cozy: Evolving collaborations in the 21 st century. Journal of Library Administration, 52(1), 53-69. doi:10.1080/01930826.2011.629962

Kranich, N. (2005/2006). Civic partnerships: The role of libraries in promoting civic engagement. In W. Miller \& R. M. Pellen (Eds.), Libraries beyond their institutions: Partnerships that work (pp. 89-103). Binghamton, NY: Haworth Information Press.

Langley, A., Gray, E. G., \& Vaughan, K. T. L. (2006). Building bridges: Collaboration within and beyond the academic library. Oxford, England: Chandos.

Lerner, G. (1997.) Why history matters: Life and thought. New York, NY: Oxford University Press.

Linfield College, Department of Theatre and Communication Arts. (2011, June). Theatre and communication arts mission statement. Retrieved from http://www.linfield.edu/tca/tcamission.html

Linfield College, DigitalCommons@Linfield. (n.d.). Metadata entry guidelines. Retrieved from http://digitalcommons.linfield.edu/Metadata_Entry_Guidelines.pdf

Linfield College, DigitalCommons@Linfield. (2011, January). Digitization standards for DigitalCommons@Linfield. Retrieved from http://digitalcommons.linfield.edu/digitization_standards.pdf

Linfield College, Linfield Center for the Northwest. (n.d.). Objectives. Retrieved from http://digitalcommons.linfield.edu/lcn/objectives.html

Linfield College, Linfield Libraries. (n.d.). Libraries' mission statement. Retrieved from http://www.linfield.edu/linfield-libraries/nicholson-info/library-mission.html

Littlejohn, S. W., \& Foss, K. A. (2005). Theories of human communication ( $8^{\text {th }}$ ed.). Belmont, CA: Thomson Wadsworth.

Madison, D. S. (2005). Critical ethnography: Methods, ethics, and performance. Thousand Oaks, CA: SAGE 
Mathson, S. M., Sabo, R. M., \& Salisbury, J. (2009). Growing grassroots collaboration between academic and public libraries. In N. Courtney (Ed.), Academic library outreach: Beyond the campus walls (pp. 77-87). Westport, CT: Libraries Unlimited.

McElroy, E., \& Hinken, S. (2011). Pioneering partnerships: Building a demand-driven consortium ebook collection. Against the Grain, 23(3), 34-38.

Montiel-Overall, P. (2005). Toward a theory of collaboration for teachers and librarians. School Library Research. Retrieved from http://www.ala.org/aasl/aaslpubsandjournals/slmrb/slmrcontents/volume82005/theory

Pacific City Arts Association. (2007). Bylaws of the Pacific City Arts Association.

Pacific City Dorymen's Association. (2012a). Frequently asked questions. Retrieved from http://www.pcdorymen.com/faq.html

Pacific City Dorymen's Association. (2012b). Our mission. In Official site of the Pacific City Dorymen's Association. Retrieved from http://www.pcdorymen.com/.

Rissel, S., \& Noegel, J. (2010). Nestucca River country: Natives, settlers \& settlements. Pacific City, OR: Author.

Sadongei, A., Graham, M. E., \& Helm, M. (2009). Working together: E-we:mcikta: The Arizona State Museum Library and the Tohono O'odham Nation. In N. Courtney (Ed.), Academic library outreach: Beyond the campus walls (pp. 115-122). Westport, CT: Libraries Unlimited.

Saldaña, J. (2005). An introduction to ethnodrama. In J. Saldaña (Ed.), Ethnodrama: An anthology of reality theatre (pp. 1-36). Walnut Creek, CA: AltaMira Press.

Seiden, P., Pumroy, E., Medeiros, N., Morrison, A., \& Luther, J. (2002). Should three college collections add up to one research collection? A study of collaborative collection development at three undergraduate colleges. In W. Miller \& R. M. Pellen (Eds.), Cooperative efforts of libraries (pp. 189-204). Binghamton, NY: Haworth Information Press.

Shepherd, M. (2004, May-June). Library collaboration: What makes it work? Paper presented at the 25th IATUL Conference, Krakow, Poland. Retrieved from http://iatul.org/doclibrary/ public/Conf Proceedings/2004/Murray20Sheperd.pdf

Spang, L., \& Yee, S. G. (2009). University library outreach in an urban setting: Forming partnerships with cultural institutions as a community service. In N. Courtney (Ed.), Academic library outreach: Beyond the campus walls (pp. 105-114). Westport, CT: Libraries Unlimited.

Taylor, J. E., III. (1990). A persistent calling: The commercial fishing history of Pacific City, Oregon (Honors thesis). Eugene: University of Oregon.

Taylor, J. E., III. (1991). For the love of it: A short history of commercial fishing in Pacific City, Oregon. Pacific Northwest Quarterly, 82(1), 22-32.

Todaro, J. B. (2005). Community collaborations at work and in practice today: An a to z overview. Resource Sharing \& Information Networks, 18(1-2), 137-156. doi:10.1300/J121v18n01_11

Tucker, T. (2009). Partnerships beyond the university campus: Community connections that work. In N. Courtney (Ed.), Academic library outreach: Beyond the campus walls (pp. 181-189). Westport, CT: Libraries Unlimited.

Voge, S. (1998). NOAH-New York Online Access to Health: Library collaboration for bilingual consumer health information on the Internet. Bulletin of the Medical Library 
Association, 86(3), 326-334. Retrieved from

http://www.ncbi.nlm.nih.gov/pmc/articles/PMC226378/ 